\title{
EFFECT OF COMPOSTED MUNICIPAL SOLID WASTE ON GROWTH, NUTRITIONAL STATUS AND FRUIT QUALITY OF APPLE TREES GROWN IN SANDY SOIL: ORGANIC FARMING
}

(Received:16.11.2006)

\author{
By \\ R.A. El-Motaium \\ Plant Research Department, Nuclear Research Center, Atomic Energy Authority, Inshas P.O.Box 13759, \\ Egypt
}

\begin{abstract}
Composted municipal solid waste (MSW) has recently received a lot of attention as a major organic fertilizer for horticulture crops grown in sandy soils. The objective of this study was to investigate the possibility of using composted municipal solid waste as the main fertilizer for apple trees (grown in sandy soil) to substitute mineral fertilizers. The study also included MSW effect on the tree nutritional status, growth and fruit quality of apples.

A field experiment at the Plant Research Department Experimental Farm, Atomic Energy Authority, using four year old apple trees (cv. Anna. grafted on Malling Merton 106 rootstock). The trees were arranged in a completely randomized block design. The soil is sandy, infertile, and almost nil in nitrogen, phosphorus and organic matter. Apple trees received MSW at two application rates, $100 \%$ and $200 \%$ of their nitrogen optimum recommended rate. This is equivalent to 72 and $144 \mathrm{Kg} \mathrm{N} / \mathrm{ha}$, respectively. The control treatment received mineral fertilizer (NPK) at the optimum recommended rate for apple trees.

The results obtained indicate that the application of MSW to sandy soils has improved its physical and chemical properties, provided the soil and plant with nutrients and increased the yield comparing with the control (mineral fertilizers). Significant increase in tree growth (shoot length, trunk diameter), number of buds formed, fruit set and leaf chlorophyll content occurred as a result of using MSW comparing with the control. The nutritional status of the tree $(\mathrm{N}, \mathrm{P}, \mathrm{K}, \mathrm{Ca}, \mathrm{Mg}, \mathrm{Fe}, \mathrm{Mn}, \mathrm{Zn}, \mathrm{Cu})$ in the leaf and fruit has shown sufficient concentrations of macro and micro nutrients for adequate apple tree growth. Heavy metals in the leaf and fruit were far below the toxic limits comparing with the international standard. Improved fruit quality was obtained under MSW fertilization system. Composted municipal solid waste has provided apple trees with their essential nutrients. The higher MSW application rate (200\% N requirement) showed higher fruit yield than the lower MSW application rate (100\% N requirement) and the control.
\end{abstract}

Key words: bud break, chlorophyll content, fruit set, heavy metals, micro and macro-nutrients, NPK, total sugar, trunk diameter, TSS.

\section{INTRODUCTION}

Outside the Nile valley and the Delta, the agricultural soils in Egypt are mainly sandy soils. Sandy soil is a characteristic of arid and semi-arid regions. In Egypt, being a semi-arid country, agriculture consumes about $90 \%$ of the available fresh water. Sandy soil is characterized by being poor in nutrients and organic matter content. Growing fruit trees in such a soil requires a lot of fertilizer input to insure high fruit production. The application of organic waste into sandy soil to improve its productivity was reported by Hornick and Parr, (1987). Municipal solid waste (MSW) is a good example of such waste that could be recycled as an organic fertilizer. It contains high organic matter and high macro and micro- nutrients which help to improve soil physical and chemical characteristics (Vogtman and Fricke, 1989).

Apple tree is the most common fruit tree that is grown in cold and moderate temperature region of the world. Apple fruits in the Egyptian markets used to be imported from Europe and/or the USA. However, recently some cultivar with less chilling requirements were introduced to the sub-tropical and temperate regions, e.g. apple cv.Anna. In Egypt, apple cv. Anna is considered a new cultivar that was introduced to the country since 1979 ( Stino, 1992). The total cultivated area of apples in Egypt is estimated to be 85,000 (acre) Feddan $\left(1\right.$ Feddan $\left.=4200 \mathrm{~m}^{2}\right)$ according to Stino (1992). This area is increasing, This area is 
increasing as the demand for local consumption exceedes the supply. The apple fruit has high nutritional value, it contains sugars, nitrogen, amino acids, organic acids, vitamins (A \& C), fibers, potassium, iron, calcium and volatile compounds (Stino, 1992).

Organic farming for growing fruit trees in Egypt is a new trend and an effective option for recycling of MSW. Municipal solid waste is a good substitute for mineral fertilizers which are costly. Few studies have been reported regarding the use of municipal solid waste as a fertilizer for growing apple trees. The objectives of this investigation were: 1) to study the effect of fertilization with municipal solid waste on apple tree growth, nutrition status of apple tree and fruit quality 2) to investigate the effect of fertilization with municipal solid waste on sandy soil physiochemical properties.

\section{MATERIALS AND METHODS}

One year old apple seedlings (Anna grafted on Malling Merton 106 rootstock) were transplanted in a field experiment at the Plant Research Department Experimental Farm, Atomic Energy Authority. The experiment started after three years from transplanting, (4 year old trees) and continued for three successive years $(2002,2003$ and 2004). The trees were arranged in a completely randomized block design. Each block included three treatments, and each treatment was replicated five times. The soil used is classified as being sandy soil (Typic Torripsamments) according to Soil Survey Staff (1975). This soil is virgin, infertile and poor in nitrogen, phosphorus and organic matter. Physical and chemical properties of the soil were determined and shown in Table (1).

Table (1): Physical and chemical properties of the Soil used.

\begin{tabular}{|l|c|c|}
\hline Sandy soil & Unit & Value \\
\hline $\begin{array}{l}\text { Texture } \\
\text { sand }\end{array} \begin{array}{l}\text { silt } \\
\text { clay }\end{array}$ & $\%$ & 95.0 \\
\hline pH & $\%$ & 2.4 \\
\cline { 2 - 3 } $\begin{array}{l}\text { Organic } \\
\text { matter }\end{array}$ & $\%$ & 2.6 \\
\hline Total N & $\mathrm{g} \mathrm{kg}^{-1}$ & 0.0 \\
\hline Total P & $\mathrm{mg} \mathrm{kg}^{-1}$ & 0.03 \\
\hline
\end{tabular}

The annual application rate of organic fertilizer is usually determined on the basis of the nitrogen needs of the crop. Three treatments were applied, two using MSW and the control. Apple trees received composted municipal solid waste at $100 \%$ and $200 \%$ of the apple tree nitrogen recommended rate. This is equivalent to 72 (3t/ha MSW) and 144 (6 t/ha MSW) Kg N/ha, respectively. The control treatment received mineral fertilizer (NPK) at the optimum recommended rate for apple trees $(360 \mathrm{Kg} / \mathrm{ha}$ ammonium sulphate, $240 \mathrm{Kg} / \mathrm{ha}$ Super phosphate and $240 \mathrm{Kg} / \mathrm{ha}$ potassium sulfate). MSW was applied to each tree in two holes, $50 \mathrm{~cm}$ depth, at the limit of the root distribution area then covered by sand.

Composted MSW was obtained from the organic compost unit, Mokatum , Cairo-Egypt. The characteristics of MSW are shown in Table (2), which demonstrate that MSW is high in organic matter content, NPK and micronutrients.

Table (2): General characteristics of Municipal Solid Waste
\begin{tabular}{|l|c|}
\hline Variables & Municipal Solid Waste \\
\hline Organic matter (\%) & 52 \\
\hline Density $\left(\mathbf{g} / \mathbf{c m}^{\mathbf{3}}\right)$ & 0.7 \\
\hline pH & 6.6 \\
\hline Macro-nutrient content (\%) & 2.4 \\
\hline Total N & 0.65 \\
\hline Total P & 1.5 \\
\hline Total K & \\
\hline Total Heavy metals $(\boldsymbol{\mu g} / \mathbf{g})$ & 800 \\
\hline Zn & 360 \\
\hline Mn & 5700 \\
\hline Fe & 420 \\
\hline Cu & 2.0 \\
\hline Cd & 400 \\
\hline Pb & 9.0 \\
\hline Cr & \\
\hline
\end{tabular}

\subsection{Determination of MSW and soil} characteristics

Different parameters were measured to determine the general characteristics of MSW and the soil after three years of MSW application. The $\mathrm{pH}$ value was determined in a $(1: 2.5)$ soil:water suspension using $\mathrm{pH}$ meter (Orion), macro nutrients NPK and heavy metals were determined according to Westerman (1990). Municipal solid waste density was calculated by measuring the volume of certain weight. Organic matter content was determined according to (Klute, 1986), Water holding capacity (WHC), cation exchange capacity (CEC) and Bulk density were determined according to (Power and Dick, 2000).

\subsection{Determination of apple tree growth parameters \\ 2.2.1 Bud break}

Broken flower buds of each tree in the different treatments were counted throughout the month of February and March of each year and an average number was calculated.

\subsubsection{Yield}

The number of fruits per tree in the different treatments was counted each year on the first week of June and the average was calculated 


\subsubsection{Shoot length and trunk diameter}

At the end of the growing season the average length of 10 shoots (current growth) was
$\mathrm{KgN} / \mathrm{ha}$ ) MSW application rate was 2.5, 2.8 and 4.1 fold for the three successive years, respectively.

Table (3): Effect of fertilization with MSW on bud break( \# buds/tree)

\begin{tabular}{|c|c|c|c|c|c|c|c|c|c|c|c|c|}
\hline \multirow[t]{2}{*}{ Treat. } & \multicolumn{4}{|c|}{2002} & \multicolumn{4}{|c|}{2003} & \multicolumn{4}{|c|}{2004} \\
\hline & $7 / 2$ & $22 / 2$ & $7 / 3$ & $22 / 3$ & $7 / 2$ & $22 / 2$ & $7 / 3$ & $22 / 3$ & $7 / 2$ & $22 / 2$ & $7 / 3$ & $22 / 3$ \\
\hline $\begin{array}{l}\text { MF } \\
\text { (Control) }\end{array}$ & 20 & 26 & 30 & 34 & 23 & 25 & 28 & 34 & 25 & 28 & 31 & 38 \\
\hline $\begin{array}{l}\text { MSW } \\
100 \% \mathrm{~N}\end{array}$ & 43 & 65 & 80 & 90 & 80 & 92 & 99 & 102 & 83 & 96 & 103 & 107 \\
\hline $\begin{array}{l}\text { MSW } \\
200 \% \mathrm{~N}\end{array}$ & 53 & 70 & 85 & 96 & 86 & 93 & 101 & 140 & 89 & 97 & 105 & 145 \\
\hline LSD 0.05 & 7.3 & 12.2 & 14.3 & 16.3 & 8.4 & 8.9 & 11.4 & 8.3 & 8.1 & 5.3 & 3.2 & 7.5 \\
\hline
\end{tabular}

calculated. At the same time the average trunk diameter of 10 trees of the different treatments was calculated.

\subsection{4. leaf chlorophyll contents}

Fully expanded mature leaves representing the different treatments were used immediately after harvest to determine the chlorophyll content according to Inskeep and Bloom (1985) .

\subsection{Determination of fruit quality parameters:}

The percentages of total soluble solids (TSS) and total sugars contents were determined in the fruits according to A.O.A.C. (1985). Heavy metals content in the fruits was determined as described by Westerman (1990).

\subsection{Determination of apple tree nutritional status}

Apple tree nutritional status macro $(\mathrm{N}, \mathrm{P}, \mathrm{K}$, $\mathrm{Ca}, \mathrm{Mg}$ ) and micro- nutrients ( $\mathrm{Fe}, \mathrm{Zn}, \mathrm{Mn}, \mathrm{Cu})$ as well as heavy metals $(\mathrm{Pb}, \mathrm{Ni}, \mathrm{Co}, \mathrm{Cd}, \mathrm{Cr})$ were determined in the leaves according to Westerman (1990) and analyzed by the Atomic Absorption Spectrometry (Shimadzu).

The data were subjected to ANOVA and significant differences among the treatment means were tested by the LSD test according to (Steel and Torrie, 1960) using SPSS statistical package.

\section{RESULTS AND DISCUSSION}

\subsection{Effect of fertilization with municipal solid} waste on apple tree growth

Apple tree growth was evaluated by measuring the following parameters: the number of bud break, yield (number fruit/tree), trunk diameter, shoot length and leaf chlorophyll content.

\subsubsection{Bud break}

Buds started to break in early February and lasted till the end of March. The number of broken buds was significantly higher under municipal solid waste application regime than the control (MF) Table (3). Relative to the control the increase in the number of broken buds, at (144

\subsubsection{Yield}

Yield is the main component that reflects the effect of certain treatment on tree growth and development. Data presented in Table (4) show that the yield, expressed as the number of fruits/tree, was affected by municipal solid waste application for the three successive years. The number of fruits/tree was significantly greater in trees grown in plots which received composted municipal solid waste ( 72 and $144 \mathrm{~kg} \mathrm{~N} / \mathrm{ha}$ ) than the control plots (received mineral fertilizer) for the three successive years (2002, 2003 and 2004). The increase in yield relative to the control treatment was: $300 \%$ and $338 \%$ for the first year; $286 \%$ and $357 \%$ for the second year; $226 \%$ and $274 \%$ for the third year at MSW application rate of 72 and $144 \mathrm{kgN} / \mathrm{ha}$, respectively. The increase in yield as a result of MSW application at $100 \% \mathrm{~N}$ and $200 \%$ rates relative to the control was more pronounced than the increase in yield between $100 \% \mathrm{~N}$ and $200 \% \mathrm{~N}$ applications rates. This less increase in yield using $200 \% \mathrm{~N}$ application rates relative to $100 \% \mathrm{~N}$ could be due to the imbalance between the vegetative and the reproductive growth. At $200 \% \mathrm{~N}$ application rate the trees showed vigorous growth and more vegetative volume than the trees received $100 \%$ of $\mathrm{N}$ recommended rate, this is in turn was reflected on the reproductive growth (number of fruits).

Table (4): Effect of fertilization with MSW on apple tree yield ( number of fruits/tree)

\begin{tabular}{|l|c|c|c|}
\hline Treatments & $\mathbf{2 0 0 2}$ & $\mathbf{2 0 0 3}$ & $\mathbf{2 0 0 4}$ \\
\hline MF (Control) & 65 & 90 & 95 \\
\hline MSW, $100 \% \mathrm{~N}$ & 150 & 200 & 215 \\
\hline MSW, 200\%N & 170 & 250 & 260 \\
\hline LSD 0.05 & 12.9 & 24.0 & 10.2 \\
\hline
\end{tabular}

\subsubsection{Shoot length and trunk diameter}

Shoot length, tree size and trunk diameter are good indications for tree growth. Data presented in Table (5) show an increase in shoot length and trunk diameter as a result of municipal solid waste application relative to the control. These results 
held true during the three years of study. During the three years of this study shoot length was significantly higher at MSW application rate of $200 \% \mathrm{~N}$ than at MSW application rate of $100 \% \mathrm{~N}$ of the recommended rate. Trunk diameter showed

\subsection{Effect of fertilization with MSW on apple fruit quality}

3.2.1. Total soluble sugars and total soluble solids

The soluble sugar content was significantly

Table (5): Effect of fertilization with MSW on apple tree growth (trunk diameter and shoot length

\begin{tabular}{|c|c|c|c|c|c|c|}
\hline \multirow[t]{2}{*}{ Treatments } & \multicolumn{2}{|c|}{2002} & \multicolumn{2}{|c|}{2003} & \multicolumn{2}{|c|}{2004} \\
\hline & $\begin{array}{l}\text { Shoot length } \\
(\mathrm{cm})\end{array}$ & $\begin{array}{c}\text { Trunk } \\
\text { diameter } \\
(\mathrm{cm})\end{array}$ & $\begin{array}{l}\text { Shoot length } \\
(\mathrm{cm})\end{array}$ & $\begin{array}{c}\text { Trunk } \\
\text { diameter }(\mathrm{cm})\end{array}$ & $\begin{array}{l}\text { Shoot length } \\
(\mathrm{cm})\end{array}$ & $\begin{array}{c}\text { Trunk } \\
\text { diameter }(\mathrm{cm})\end{array}$ \\
\hline MF (Control) & 70.8 & 6.8 & 80.0 & 10.0 & 83.0 & 12.0 \\
\hline MSW, $100 \% \mathrm{~N}$ & 86.3 & 11.3 & 88.3 & 14.6 & 90.0 & 16.0 \\
\hline MSW, $200 \% \mathrm{~N}$ & 100.5 & 13.6 & 108.2 & 16.1 & 111.0 & 18.0 \\
\hline LSD 0.05 & 2.3 & 3.5 & 1.7 & 3.9 & 4.7 & 2.6 \\
\hline
\end{tabular}

no significant differences at the second and third years of between the high and the low MSW application rates. However, significant differences in trunk diameter were maintained between the trees grown in MSW amended soil and the control throughout the study period.

\subsubsection{Chlorophyll content}

Total chlorophyll content significantly increased as a result of MSW application, which indicates an increase in growth and carbohydrate ynthesis (Table 6). The increase in chlorophyll content was more pronounced at the higher MSW application rate $(200 \% \mathrm{~N})$. This results held true throughout the experiment period, the three years of study. The increase in chlorophyll content could be due to high $\mathrm{Mg}$ and $\mathrm{Fe}$ supplied by MSW. The Mg content of the leaves was greater than the control by the following folds: 1.3 and 1.5 for the first year; 1.2 and 1.5 for the second year and 1.2 and 1.4 for the third year at $100 \%$ and $200 \%$ of $\mathrm{N}$ recommended rate, respectively. Also, the iron content was higher in the leaves under MSW application regimes than the control. The results agree with El-Motaium and Abo El(Seoud2004) who found an increase of chlorophyll content in Fennel shoot grown in sandy soil(amended with sewage sludge paring with the control (mineral fertilizer). Magnesium and iron are required elements for chlorophyll biosynthesis (Marschner, 1986). The chlorophyll molecule contains a central $\mathrm{Mg}^{2+}$ ion (Hoober, 1984) which is a major component of the molecule.

Table (6): Effect of fertilization using MSW on total chlorophyll content of Apple Leaves

\begin{tabular}{|l|c|c|c|}
\hline \multirow{2}{*}{ Treatments } & $\mathbf{2 0 0 2}$ & $\mathbf{2 0 0 3}$ & $\mathbf{2 0 0 4}$ \\
\cline { 2 - 4 } & \multicolumn{3}{|c|}{$\mathbf{m g / 1 0 0 g}$ (F.W.) } \\
\hline MF (Control) & 32.2 & 34.0 & 36.0 \\
\hline MSW, 100\% N & 43.7 & 46.0 & 49.0 \\
\hline MSW, 200\% N & 54.0 & 58.2 & 60.0 \\
\hline LSD 0.05 & 2.0 & 6.5 & 6.7 \\
\hline
\end{tabular}

higher in the plants grown in the soil amended with municipal solid waste than the control Table (7). The statistical analysis shows that, no significant differences were observed between the mineral fertilizer and MSW on total soluble solids and total sugars during the first year. Fruit total sugar content significantly increased during the second and third year as a result of MSW application at $200 \% \mathrm{~N}$ recommended rate. Total soluble solids showed progressive increase over the years under the three treatments, whereas it showed significant increase under MSW application relative to the control, at the third year only. Similar results were obtained by Pandya et al.,( 1989) who observed an increase in protein, total soluble sugars and starch content in chickpea plants grown in soil amended with sewage sludge relative to the control (soil without sludge). The increase in fruit ugar content may result from the increase in chlorophyll content which is accompanied by an increase in leaves photosynthetic capacity. The linear regression (Fig. 1) between the chlorophyll and the sugars contents $\left(R^{2}=0.85\right)$ proves the relationship between the two parameters.

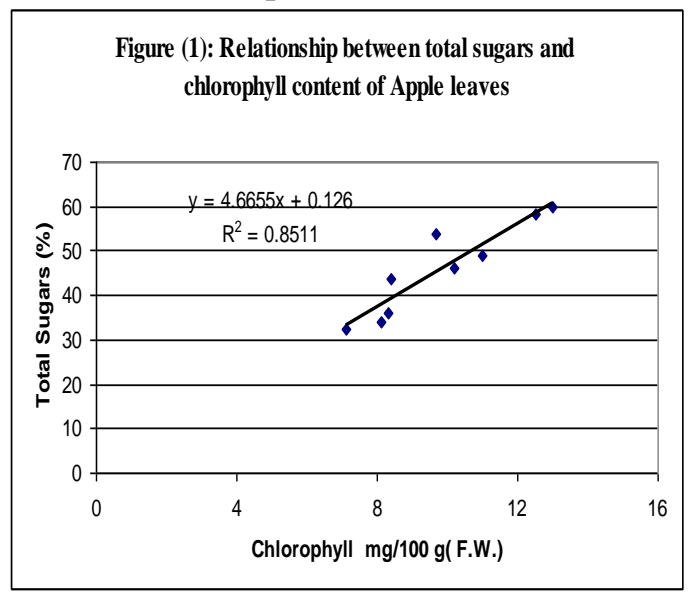

Figure(1) : Relationship between total sugars and chlorophyll content of Apple leaves 


\subsubsection{Heavy metal}

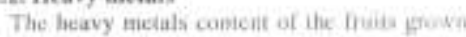
under organic waste apolication is a vef, important critcrion to decerimiac its usuality wis

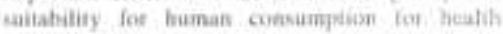
reasons. The daia exhibued a stight increase in heavy meial concentrations in the years of sypolications increased. Cuhati and testmism wers Amosit sil in apsle fraits. Apple frois croniamed small tractios of heavy melats ielutive to the lestus,

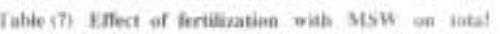

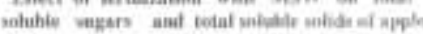
frail

\begin{tabular}{|c|c|c|c|c|c|c|}
\hline \multirow[t]{2}{*}{ Thatueas } & \multicolumn{2}{|c|}{2001} & \multicolumn{2}{|c|}{3000} & \multicolumn{2}{|c|}{$\operatorname{din} 4$} \\
\hline & $\begin{array}{l}\text { Towel } \\
\text { Canean }\end{array}$ & 78 & $\begin{array}{l}\text { Tutai } \\
\text { Suyser }\end{array}$ & TW4 & $\begin{array}{l}\text { Foist } \\
\text { tagan }\end{array}$ & $\begin{array}{c}135 \\
5\end{array}$ \\
\hline $\begin{array}{l}\text { Mir } \\
\text { itimant4 }\end{array}$ & 71 & 129 & 6 & 125 & 8.3 & 1411 \\
\hline $\begin{array}{l}\text { MNW } \\
\text { MEN }\end{array}$ & KA & 136 & 102 & 153 & $11 \mathrm{~A}$ & thet \\
\hline $\begin{array}{l}\text { MsW } \\
\text { mons }\end{array}$ & if & 14.8 & 133 & 10.4 & Ira & ita \\
\hline cxboge & 2,3 & 21 & 37 & 21 & 24 & 17 \\
\hline
\end{tabular}

Derieg the thind year of MSW appleathate. the percealses of heavy metuls in the tmiss rebative to those in the leaves wain at fodluws: $\mathrm{Pb}=23, \mathrm{Ni}=3.2, \mathrm{Co}=0.83, \mathrm{Cd}=0 \mathrm{x}, \mathrm{Cr}, \mathrm{C}$.4 for

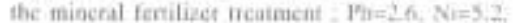
Coul0.47, Cd=0.88, CY=K:2 for MSW at $160 \mathrm{~N}$ application rate treaimen and $\mathrm{Fh}=4 \mathrm{~A}, \mathrm{Ni}=5, \mathrm{~K}$,

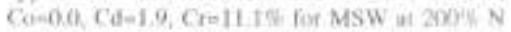
anpication rutes. The coecentuations of hessy motads stowen in Tuble (B) indicate it slimin increase in beavy metals by weing MSW

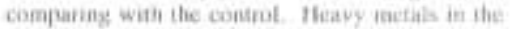
fruits under this study did not reach the excestive levels that harm plant gow ih of hamsa fiealih. Aller thece yeass af application the cosoceniraison of the studicd heavy metals ( $\mathrm{Pb}, \mathrm{Ni}, \mathrm{Co}, \mathrm{Cd}, \mathrm{Cr}$ ) wete tar bokns the waxic level far frim consumpcion sated by Domald (1V72), which are

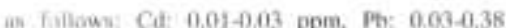
pron, Nv: 0.000.0.34 prim. Particularty for Cd which in of maior conceris in foxid crops (Girant ef 41. 1908) Cafmium concentration in apple fruits

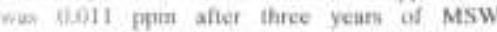
application, Growing apple trees for three years winie MSW was safe for human consumpion.

3.1. Fffect of fertilization with MSW on the suiritien atatus of apple tree

3.3.1. Macro nutrient:

Datie in Thatie (Y) sliow the percealage of NPX, Ca and $\mathrm{Mg}$ in apple loaves. Tbe five mentionat elements were used is a tool to crafuace the autritsonal statun of the apple trees. Tren jown in municipal solid waste amended plosis extobited eidher equal or higher persentaige of $\mathrm{MFK}$, Co ind $\mathrm{Mg}$ melative is the control. The ditferenice was more stear an the years of application advanced. This could be doe to the mincrafizatiog and relcase of these autrienis from their organic form over the years. In eeneral, arpile leaves accumblated greater amonat sit macro-auirienss $\left(N, P, K, C a, M_{k}\right)$ trum the wat amended with municigal solid wasie than from the oouterol (miacral ferilizer)

3.3.2. Microautrieats

Within cerlain concentratios tange, nutricni hruvy actals ( $F v, \mathrm{Mn}, \mathrm{Zn}$ und $\mathrm{Cu}$ ) atc essectitial arinients teyuitod for plant stowith and doveleppasus (Manscheser, 1986). Data in Tuble (1ii) show the micronutricat heavy metals content of apple leaves. Under MSW application there what a foudeary for an inctrisse in micromerieat cemetent as the years of application udvanced. fones of af, (1991) stated that the mictonatrients hafficieni coneveiration range for leaves of apple ITwes as bollowe Fo (50-300 ppm). Mn (25-200) mins) Zn (30-105) ppme. Cu (b-50 pom). Muaicinal solid waste sapplied apple trees with wufficient amounat of nutricen ( $\mathrm{Fe}, \mathrm{Mn}, \mathrm{Zn}, \mathrm{Cu}$ ) as mentioned by Marschere (1986) and Jonen of al., (1001)

\begin{tabular}{|c|c|c|c|c|c|c|c|c|c|c|c|c|c|c|c|}
\hline \multirow[t]{2}{*}{ Imat: } & \multicolumn{6}{|c|}{ गक् } & \multicolumn{5}{|c|}{2100} & \multicolumn{4}{|c|}{1004} \\
\hline & 19 & ). & $\mathrm{Cu}$ & ta & 6 & to & 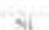 & $\frac{m y b}{6 a t}$ & Id & $\Leftrightarrow$ & 124 & Ni & $f=$ & I & I \\
\hline si & (111) & 11000 & aiu & Wasi: & dit & बivi & (⿻一丿) & जक्री & ausi & ant & เที & bain & उका & बहल & कin \\
\hline $\begin{array}{l}\text { Mink } \\
\text { jouses }\end{array}$ & 871 & 1114 & aii & सini & 2.12 & inii & 213 & inent? & 004 & (11) & 1112 & 811 & aine & a.6\% & $01 \%$ \\
\hline Mxw & 672 & "11" & घh: & yoiz & witi & if 3 ii & 6क्ष & wair & तो & c3i & 221 & 1035 & 0iki & 6011 & 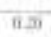 \\
\hline 150 & ais & aili & A cuiv" & สй & tiin & iiils & ins & एका & ilot? & $\pi$ in & बire & (904: & तivi & inivei & 0109 \\
\hline
\end{tabular}


Table (9): Effect of fertilization with MSW on the macronutrients content on apple leaves.

\begin{tabular}{|c|c|c|c|c|c|c|c|c|c|c|c|c|c|c|c|}
\hline \multirow{3}{*}{ Treats } & \multicolumn{5}{|c|}{2002} & \multicolumn{5}{|c|}{2003} & \multicolumn{5}{|c|}{2004} \\
\hline & \multicolumn{15}{|c|}{$\%$} \\
\hline & $\mathbf{N}$ & $\mathbf{P}$ & $\mathbf{K}$ & $\mathbf{C a}$ & Mg & $\mathbf{N}$ & $\mathbf{P}$ & $\mathbf{K}$ & $\mathbf{C a}$ & $\mathbf{M g}$ & $\mathbf{N}$ & $\mathbf{P}$ & $\mathbf{K}$ & $\mathbf{C a}$ & Mg \\
\hline $\begin{array}{l}\text { MF } \\
\text { Control }\end{array}$ & 2.3 & 0.30 & 1.55 & 0.85 & 0.26 & 2.5 & 0.31 & 1.50 & 0.90 & 0.30 & 2.5 & 0.32 & 1.50 & 0.91 & 0.32 \\
\hline $\begin{array}{l}\text { MSW } \\
100 \% \mathrm{~N}\end{array}$ & 2.4 & 0.31 & 1.56 & 0.90 & 0.34 & 2.5 & 0.33 & 1.57 & 0.92 & 0.36 & 2.6 & 0.35 & 1.60 & 0.94 & 0.38 \\
\hline $\begin{array}{l}\text { MSW } \\
200 \% \mathrm{~N}\end{array}$ & 2.5 & 0.35 & 1.60 & 0.93 & 0.40 & 2.7 & 0.36 & 1.62 & 0.99 & 0.45 & 2.8 & 0.39 & 1.65 & 1.00 & 0.46 \\
\hline $\begin{array}{l}\text { LSD } \\
0.05\end{array}$ & 0.26 & 0.03 & 0.07 & 0.03 & 0.03 & 0.21 & 0.03 & 0.11 & 0.01 & 0.03 & 0.31 & 0.01 & 0.19 & 0.06 & 0.06 \\
\hline
\end{tabular}

Table (10): Effect of fertilization with MSW on the micronutrient content of apple leaves.

\begin{tabular}{|c|c|c|c|c|c|c|c|c|c|c|c|c|}
\hline \multirow[t]{3}{*}{ Treat. } & \multicolumn{4}{|c|}{2002} & \multicolumn{4}{|c|}{2003} & \multicolumn{4}{|c|}{2004} \\
\hline & \multicolumn{12}{|c|}{$\mathrm{mg} \mathrm{kg}^{-1}$} \\
\hline & $\mathbf{F e}$ & Mn & $\mathbf{Z n}$ & $\mathbf{C u}$ & $\mathbf{F e}$ & Mn & $\mathbf{Z n}$ & $\mathbf{C u}$ & $\mathbf{F e}$ & Mn & $\mathbf{Z n}$ & $\mathbf{C u}$ \\
\hline $\begin{array}{l}\text { MF } \\
\text { Control }\end{array}$ & 177 & 23.8 & 24.7 & 12.6 & 205 & 24.0 & 25.3 & 11.5 & 206 & 24.0 & 26.0 & 13.0 \\
\hline $\begin{array}{l}\text { MSW } \\
100 \% \mathrm{~N}\end{array}$ & 250 & 29.1 & 29.1 & 15.3 & 270 & 21.1 & 36.9 & 14.7 & 274 & 23.0 & 38.0 & 15.0 \\
\hline $\begin{array}{l}\text { MSW } \\
200 \% N\end{array}$ & 275 & 30.3 & 32.1 & 16.5 & 280 & 24.8 & 38.5 & 15.6 & 287 & 25.0 & 39.2 & 17.0 \\
\hline $\begin{array}{l}\text { LSD } \\
0.05\end{array}$ & 9.16 & 2.37 & 0.39 & 0.40 & 9.16 & 1.76 & 0.69 & 0.23 & 3.5 & 2.3 & 3.4 & 3.5 \\
\hline
\end{tabular}

\subsubsection{Heavy metals}

Data in Table (11) represent the heavy metal content in apple leaves under mineral and MSW application regimes. The heavy metals were measured to study the effect of the different fertilizers on the accumulation of such metals in the leaves for three successive years. The concentrations of $\mathrm{Pb}, \mathrm{Ni}, \mathrm{Co}, \mathrm{Cd}, \mathrm{Cr}$ varied in response to the kind of fertilizer, application rates and duration. Most of the studied metals showed a slight increase relative to the control using MSW except cadmium. Cadmium was slightly higher in tree leaves grown using mineral fertilizer, however the increase was non-significant. Phosphate fertilizers are known as an important source of Cd (Fleischer et al., 1974). This could be explained by the fact that superphosphate fertilizer used in this study contains a high level of cadmium. There was an increase in leaf heavy metal concentration over the years which could be attributed to the oxidation of organic matter (resulted from high heat and aeration in sandy soil) which could release metals into more soluble form. This is explained by "the time bomb hypothesis", McBride (1995).

Heavy metals in leaf tissues were within the acceptable limits stated by Ryan and Bryndzia (1998) and are below the toxic plant concentration summarized by Chaney (1983). These toxic plant concentrations for productivity or food chain safety are as follows $(\mathrm{Pb}=2-5, \mathrm{Ni}=$ $0.1-5, \mathrm{Cd}=0.2-0.8 \mathrm{mg} / \mathrm{kg} \mathrm{D}$.W.). The reason for maintaining such low heavy metals concentrations in the leaves could be due to the distribution of such metals in the whole tree structure, dilution effect.The calculated soil $\mathrm{Cd}$ concentrations using MSW $(\mathrm{Cd}$ content $=2 \mathrm{mg}$ $\mathrm{kg}^{-1}$ ) as a fertilizer in sandy soil showed that Cd concentration was $0.0025 \mathrm{mg} \mathrm{kg}^{-1}$ and $0.0050 \mathrm{mg}$ $\mathrm{kg}^{-1}$ under the application of $100 \%$ and $200 \%$ of $\mathrm{N}$ recommended rate. This concentration is very low comparing with the maximum concentration of $3 \mathrm{mg} \mathrm{kg}$-1 allowed under the EU legislation (CEC, 1986) and is much lower than the Cd concentration of $20 \mathrm{mg} \mathrm{kg}^{-1}$ allowed by the EPA503 regulation (USEPA, 1993).

\subsection{Effect of fertilization with MSW on sandy soil properties}

Table (12) shows the improvement in soil characteristics after three years of successive MSW application. The improvement was shown in the reduction in soil $\mathrm{pH}$ and bulk density and in the increase in soil organic matter, water holding capacity and cation exchange capacity relative to the control treatment. These results are in close agreement with El-Motaium and Badawy, (2002) using sewage sludge. Also, the increase in soil $\mathrm{N}, \mathrm{P}, \mathrm{K}$ at $144 \mathrm{Kg} \mathrm{N} / \mathrm{ha} \mathrm{MSW}$ application rate reached $12,10,12$ fold respectively, relative to the control. The improvement in soil physical properties can play a better role in increasing crop productivity than the role of the nutrients content. 
Table (11): Effect of fertilization with MSW on heavy metal contents of apple leaves

\begin{tabular}{|c|c|c|c|c|c|c|c|c|c|c|c|c|c|c|c|}
\hline \multirow[t]{3}{*}{ Treat. } & \multicolumn{5}{|c|}{2002} & \multicolumn{5}{|c|}{2003} & \multicolumn{5}{|c|}{2004} \\
\hline & \multicolumn{15}{|c|}{$\mathrm{mg} \mathrm{kg}^{-1}$} \\
\hline & $\mathbf{P b}$ & $\mathbf{N i}$ & Co & Cd & $\mathrm{Cr}$ & $\mathbf{P b}$ & $\mathrm{Ni}$ & Co & $\mathbf{C d}$ & $\mathrm{Cr}$ & $\mathbf{P b}$ & $\mathrm{Ni}$ & Co & Cd & $\mathrm{Cr}$ \\
\hline $\begin{array}{l}\text { MF } \\
\text { Control }\end{array}$ & 2.2 & 0.98 & 0.09 & 0.55 & 1.2 & 3.3 & 2.45 & 0.12 & 0.60 & 1.2 & 3.5 & 2.5 & 0.12 & 0.61 & 1.2 \\
\hline $\begin{array}{l}\text { MSW } \\
100 \% \mathrm{~N}\end{array}$ & 3.0 & 2.19 & 0.36 & 0.50 & 1.5 & 4.1 & 3.00 & 0.41 & 0.55 & 1.6 & 4.6 & 3.3 & 0.43 & 0.57 & 1.7 \\
\hline $\begin{array}{l}\text { MSW } \\
200 \% \mathrm{~N}\end{array}$ & 3.3 & 3.09 & 0.42 & 0.53 & 1.6 & 4.8 & 3.60 & 0.45 & 0.56 & 1.7 & 4.9 & 3.8 & 0.46 & 0.58 & 1.7 \\
\hline $\begin{array}{l}\text { LSD } \\
0.05\end{array}$ & 0.61 & 0.11 & 0.06 & 0.09 & 0.26 & 0.57 & 0.56 & 0.08 & 0.01 & 0.39 & 0.80 & 0.44 & 0.04 & 0.03 & 0.36 \\
\hline
\end{tabular}

Table(12): Effect of fertilization with MSW on sandy soil physical and chemical characteristics and total nutrient content

\begin{tabular}{|l|c|c|c|c|c|c|c|c|}
\hline Treat. & $\mathbf{p H}$ & $\begin{array}{c}\mathbf{B d} \\
\mathbf{g . c m}^{-\mathbf{1}}\end{array}$ & $\begin{array}{c}\mathbf{W H C} \\
\mathbf{\%}\end{array}$ & $\begin{array}{c}\mathbf{O M} \\
\mathbf{g k g}^{-1}\end{array}$ & $\begin{array}{c}\mathbf{C E C} \\
\mathbf{m e q . 1 0 0 \mathbf { g } ^ { - 1 }}\end{array}$ & $\begin{array}{c}\mathbf{N} \\
\mathbf{\%}\end{array}$ & $\begin{array}{c}\mathbf{P} \\
\mathbf{\%}\end{array}$ & $\begin{array}{c}\mathbf{K} \\
\mathbf{\%}\end{array}$ \\
\hline Sandy soil & 8.1 & 1.70 & 10.7 & 0.1 & 2.1 & 0.03 & 0.022 & 0.025 \\
\hline MSW & 7.8 & 1.50 & 14.8 & 0.6 & 10.9 & 0.24 & 0.112 & 0.154 \\
$100 \%$ & & & & & & & & 0.36 \\
\hline $\begin{array}{l}\text { MSW } \\
\text { 200\% }\end{array}$ & 7.6 & 1.40 & 17.0 & 1.0 & 12.0 & 0.200 & 0.301 \\
\hline
\end{tabular}

These results agree with Mays and Giordano (1989) who found that land application of MSW showed favorable effects on soil properties such as $\mathrm{pH}$, increase in soil organic matter and plant nutrients. In this experiment, a reduction in sandy soil bulk density was observed under MSW

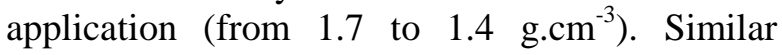
previous finding was reported by (Kreft, 1987) for field application of MSW compost which showed a reduction in bulk density of loamy sand soil.

\section{CONCLUSION}

Composted municipal solid waste could be used in sandy soil to improve soil structure, increase its water retention and cation exchange capacity and provide macro and micro-nutrients for plant growth. Apple tree growth was improved by the application of municipal solid waste. Trunk diameter, shoot length, number of bud break, fruit set and chlorophyll content were higher using MSW than the control. Apple leaf heavy metals $(\mathrm{Pb}, \mathrm{Cd}, \mathrm{Co}, \mathrm{Ni}, \mathrm{Cr})$ content were very low and NPK and micronutrients was at adequate level for healthy growth. The increase in plant mineral nutrients increased the tree growth and the yield. Fruit quality has improved by showing high content of TSS and total soluble sugars. Fruits contained traces of heavy metals, i.e. below the toxic level for safe fruit consumption. Apple tree can grow successfully in sandy soil amended with MSW with no need for mineral fertilizer. Growing apple trees for three years using MSW was safe for human consumption.

\section{REFERENCES}

Association of Official Agricultural Chemist (A.O.A.C.) (1985).Official Methods of
Analysis. $12^{\text {th }}$ ed: 494-510, Benjamin Franklin Station Washington, D.C.

CEC: Commission of the European Communities (1986). Council Directive on the protection of the environment, and in particular of the soil when sewage sludge is used in agriculture. Official Journal of the European Communities, p. 10.L81, Annex $1 \mathrm{~A}$

Chaney R.L. (1983). Potential effects of waste constituents on food chain. p. 152-240. In: Parr J.F., Marsh P.B. \& Kla JM (Eds) Land Treatment of Hazardous Wastes (p. 152240) Noyes Data Corp., Park Ridge, NJ

Donald J.L. (1972). Trace metals in soils, plants and animals. Advances in Agron. 24, p. 267-325

El-Motaium R.A. and Badawy S.H. (2002). Heavy metals $(\mathrm{Cd}, \mathrm{Co}, \mathrm{Ni}$ and $\mathrm{Pb})$ accumulation in tomato plants and soils amended with irradiated and non-irradiated sewage sludge. Egyptian J. Soil Sci. Vol. 42, No. 1-4

El-Motaium R.A. and Abo-El-Seoud M. (2004). Irradiated sewage sludge for production of fennel plants in sandy soil. Nutrient Cycling in Agroecosystem (in press)

Fleischer M., Sarofim A.F.; Fassett D.W.; Hammond P.; Shacklette H.T.; Nisbet I.C.T. and Epstein S. (1974). Environmental impact of cadmium. Environ. Health Perspect., 5, 253

Grant C.A., Buckley W.T., Bailey L.D. and Selles F. (1998). Cadmium accumulation in crops. Can.J.Plant Sci. Vol. 78, p. 1-17

Hoober J.K. (1984). Chloroplasts. Chapter 3 Characteristic eomponents of Chloroplast Membranes. Plenum Press. New York and London 
Hornick S.B. and Parr J.F. (1987). Restoring the productivity of marginal soils with organic amendments. The American Journal of Alternative Agriculture. Vol. 11, No.2 p. 64-68

Inskeep W.P. and Bloom P.R. (1985). Extinction coefficient of chlorophyll $a$ and $b$ in N,NDimethylformamide and $80 \%$ Acetone. Plant Physiology Vol. 77: 483-485

Jones J.B., Wolf Jr.B. and Mills H.A. (1991). Plant Analysis Handbook. Micro-Macro Publishing.Inc.

Klute A. (1986). Methods of Soil Analysis. Part IPhysical and Mineralogical Methods. Second Edition in the SSSA Book Series: 5. American Society of Agronomy, Inc. Soil Science Society of America, Inc. Madison, Wisconsion, USA

Kreft D. (1987). Soil Physical Properties as Influenced by the Addition of Municipal Compost. MSc Thesis. ,Univ. of Minnesota. St. Paul

Marschner H. (1986). Mineral Nutrition of Higher Plants. Academic Press. Harcourt Brace Jovanovich, Publishers

Mays D.A. and Giordano P.M. (1989). Land spreading of municipal waste compost. BioCycle 30 (3) 37-39

McBride M.B. (1995). Toxic metal accumulation from agricultural use of sludge: are USEPA regulations protective. Journal of Environmental Quality. Vol. 24, No.1, p.518.

Pandya G.A., Sachidanand S. and Modi V.V. (1989). Potential of recycling gammairradiated sewage sludge for use as a fertilizer: a study on chickpea (Cicer arietinum). Environmental Pollution 56:101-111

Power J.F. and Dick W.A. (2000). Land application of agricultural, industrial and municipal by-product. In the SSSA Book Series: 6. Soil Science Society of America, Inc. Madison, Wisconsion, USA

Ryan J.A. and Bryndzia L.T. (1998). Fate and Potential effects of Trace Elements: Issues in Co-utilization of By-Products. In: Beneficial Co-utilization of agricultural, Municipal and industrial by Products. Brown S.; Angle J.S. and Jacobs L. (Eds.) p. 219-233. Kluwer Academic Publishers, Dordrecht/ Boston/ London

Soil Survey Staff (1975). Soil Taxonomy. Agric. Handbook No. 436, USDA, Washington D.C.

Steel R.G.D. and Torrie J.H. (1960). Principles and Procedures of Statistics. McGraw-Hill Book Company, Inc. New York, Toronto, London

Stino R.G. (1992). Production of Apple in the Warm Climate Region. Dar El-Shorok, Cairo, Burit.

USEPA: United States Environmental Protection Agency (1993). Standards for the use of disposal of sewage sludge. Fed. Regist. Vol.58, p. 9248-9415

Vogtman H. and Fricke K. (1989). Nutrient value and utilization of biogenic composts in plant production. Agric. Ecosyst. Environ., 27: 471-475

Westerman R.L. (1990). Soil Testing and Plant Analysis. Third Edition in the SSSA Book Series:3 Soil Science society of America, Inc. Madison, Wisconsin, USA.

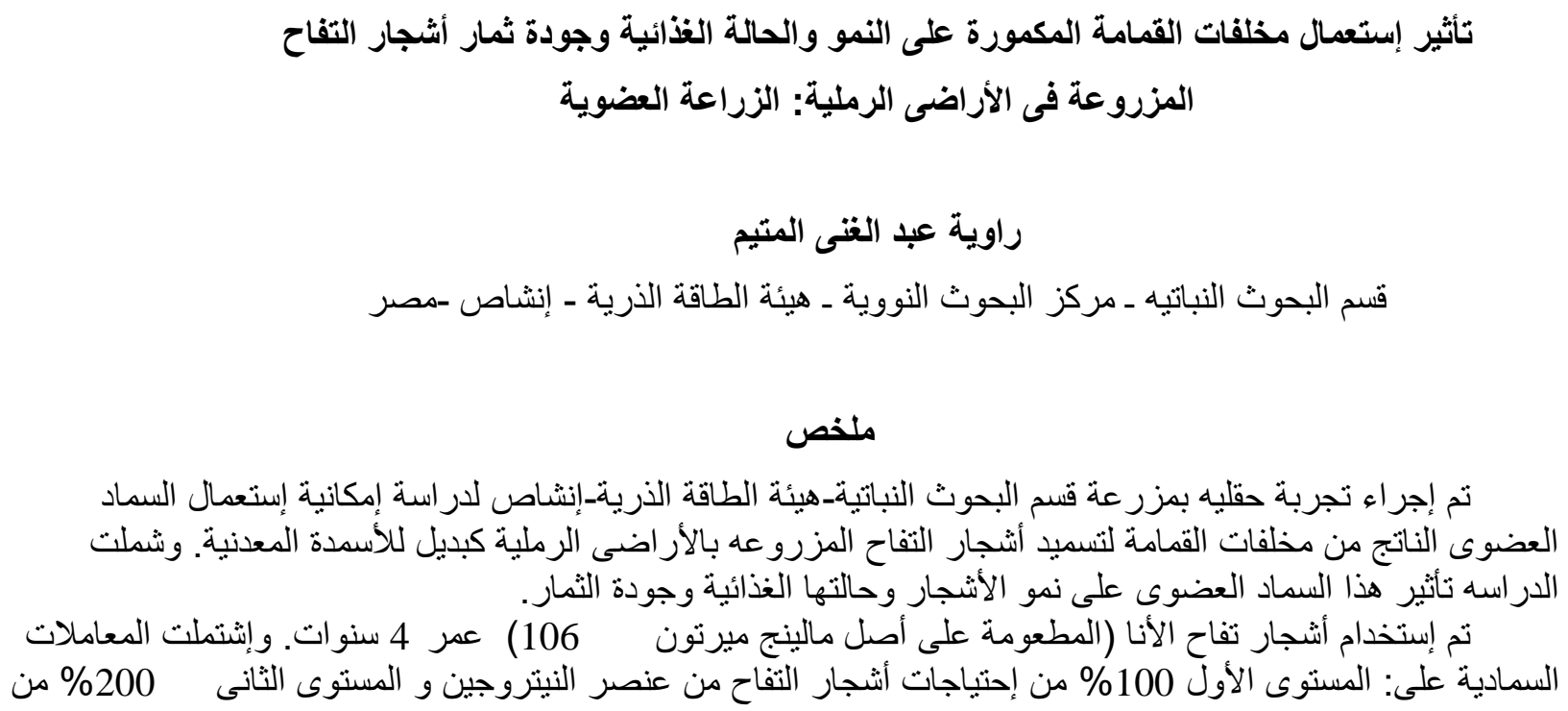


إحتياجات أشجار التفاح من عنصر النيتروجين بالاضافه إلى معامله الكنترول بإستعمال الأسمده المعدنيه بالمعدلات المثاليه.

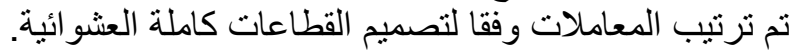

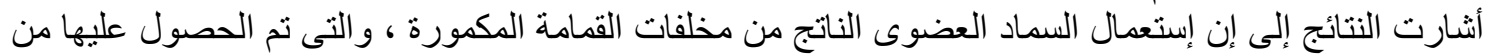

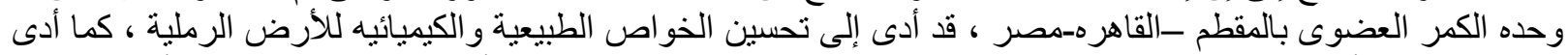

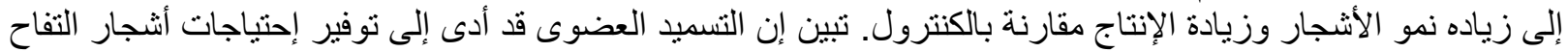

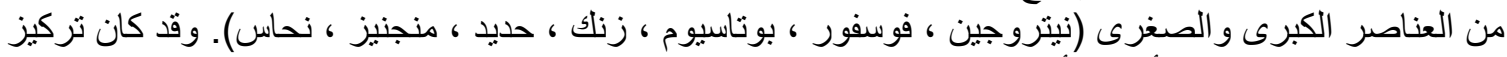

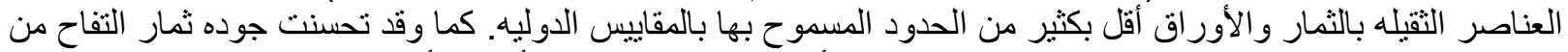

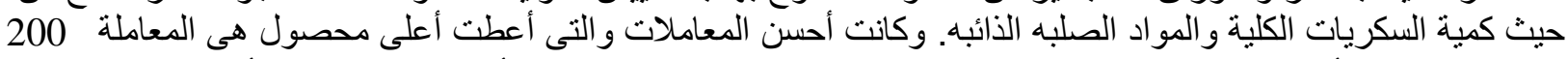

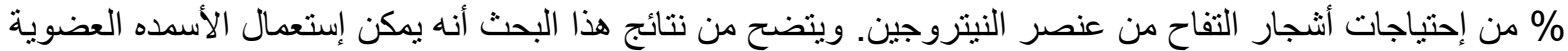
الناتجه من مخلفات القمامة و إعادة إستعمالها كسماد للأر اضى الرمليه الريه بدون الحاجه للأسمدة المعدنية.

المجلة العلمية لكلية الزر اعة ـ جامعة القاهرة ـ المجلد (58) العدد الثالث (يوليو 2007):198-206. 